\title{
ブシ末単独服用による酸化度・抗酸化力の 変化について
}

中永士師明

秋田大学大学院医学系研究科医学専攻, 病態制御医学系 救急·集中治療医学講座, 秋田, $\overline{0} 010-8543$ 秋田市本道1-1-1

\section{Clinical Evaluation of Oxidative Stress after Taking Powdered Processed Aconiti Tuber}

\author{
Hajime NAKAE \\ Department of Emergency and Critical Care Medicine, Akita University Graduate School of Medicine, Akita University School \\ of Medicine, 1-1-1 Hondo, Akita 010-8543, Japan
}

\begin{abstract}
'Processed bushi powder for ethical dispensing', or TJ-3022, is an Aconiti tuber (PAT) herbal drug, and TJ3023 is newly-developed to contain a higher proportion of diester aconitine alkaloid. We measured reactive oxygen metabolite derivative levels (d-ROMs tests), and total antioxidant capacity (OXY-adsorbent tests) in healthy adult volunteers, to assess whether PAT affects the oxidative stress regulation system. Thirty-four subjects were assigned to one of two groups : a TJ-3022 group and a TJ-3023 group. No significant chronological differences were observed in the TJ-3022 group. No significant chronological differences were observed in the TJ-3023 group, either. These results indicate that PAT dose not affect the oxidative stress regulation system in humans.

Key words : oxidative stress, total antioxidant capacity, processed Aconiti tuber

\section{要旨}

2 種類のブシ末製剤を単独で服用した場合の酸化ストレス度と抗酸化力を測定し，経時変化について検討した。 健常人34例を2 群に分けて 2 種類のブシ末製剤（TJ-3022，TJ-3023） $3 \mathrm{~g} /$ 日を 3 日間服用し，服用直前，服用90分 後, 服用72時間後に酸化ストレス度（d-ROMs テスト）と抗酸化力（OXY 吸着テスト）を測定した。TJ-3022群で は酸化ストレス度と抗酸化力の有意な経時的変化はみられなかった。TJ-3023群でも酸化ストレス度と抗酸化力の有 意な経時的変化はみられなかった。附子服用量 $3 \mathrm{~g} /$ 日では酸化ストレスに影響を及ぼさないことが示唆された。 キーワード：附子, 酸化ストレス, 抗酸化力
\end{abstract}

\section{緒言}

附子はトリカブト属植物の塊根から調整され，鎮 痛, 温熱, 新陳代謝賦活, 強心, 利尿などの作用を 目的に臨床使用される ${ }^{1)}$ 。一概にブシ末製剤といっ ても原料によって効能が異なる。TJ-3022は原料が ハナトリカブトだけであり，TJ-3023はハナトリカ ブトとオクトリカブトを一定比率で混合させている。 附子の成分中，メサコニチン，ヒパコニチン，アコ ニチン，ジェサコニチンの 4 つが鎮痛効果を発揮す る代表的なアルカロイドであるが，ハナトリカブト にはジェサコニチンが含有されていない。鎮痛効果 や抗アロデニア効果を検討する動物実験において
TJ-3022より TJ-3023の方が高い効力を示すことが報 告されている2)。我々も TJ-3022と TJ-3023を比べる と TJ-3023にのみジェサコニチンが検出されること を報告している ${ }^{3)}$ 。

酸化ストレスとは生体内で発生する活性酸素種・ フリーラジカルを含む酸化物質の生成と抗酸化反応 のバランスが崩れ, 酸化促進物質が優勢になった状 態と定義されており, 種々の疾患の発症と進展に関 与している。生体の酸化ストレス状態を総合的に評 価するには同時に抗酸化力も評価することが望まし い4)。抗酸化力を維持するためには, SOD, カタラー ゼ，グルタチオン，グルタチオンペルオキシダーゼ 
表 1 被験者背景

\begin{tabular}{lccc}
\hline & $T J-3022$ 群 $(n=17)$ & TJ-3023 群 $(n=17)$ & $P$ 值 \\
\hline 年齢(歳、中央値) & $38(23-54)$ & $40(23-56)$ & N.S \\
性 & 男性 11 例、女性 6 例 & 男性 12 例、女性 5 例 & N.S \\
投与前 d-ROMs (U.CAAR.) & $305(144-475)$ & $303(199-385)$ & N.S \\
投与前 $\mathrm{OXY}(\mu \mathrm{mol} / \mathrm{ml} \mathrm{HCIO)}$ & $331(200-390)$ & $351(245-375)$ & N.S \\
\hline
\end{tabular}

N.S: not significant

表 2 TJ-3022群の経時的変化

\begin{tabular}{lclll}
\hline & 服用直前 & 90 分後 & 72 時間後 & $\mathrm{P}$ 値 \\
\hline D-ROMs (U.CAAR. $)$ & $305(144-475)$ & $302(141-433)$ & $302(141-493)$ & N.S \\
OXY $(\mu \mathrm{mol} / \mathrm{ml} \mathrm{HClO})$ & $331(200-390)$ & $327(269-417)$ & $329(285-375)$ & N.S \\
\hline
\end{tabular}

N.S: not significant

表 3 TJ-3023群の経時的变化

\begin{tabular}{lclll}
\hline & 服用直前 & 90 分後 & 72 時間後 & P 値 \\
\hline D-ROMs (U.CAAR. $)$ & $303(199-385)$ & $291(207-389)$ & $292(214-394)$ & N.S \\
OXY $(\mu \mathrm{mol} / \mathrm{ml} \mathrm{HClO})$ & $351(245-375)$ & $343(249-379)$ & $334(267-415)$ & N.S \\
\hline
\end{tabular}

N.S: not significant

などの内因性抗酸化物質は年齢とともに減少するた め，植物に含まれるファイトケミカルなどの外因性 抗酸化物質を取り入れる必要がある。小柴胡湯，釣 藤散など漢方方剂は植物由来の生薬が含有されてい るために抗酸化力を有しているといわれている(5) 。 in vitro の研究に扮いて, ブシ末は用量依存的に $\mathrm{O}_{2}$ を除去できることが報告されている ${ }^{8)}$ 。我々はこ れまでにブシ末 $3 \mathrm{~g} /$ 日の単独服用で血流増加がみら れることを報告しており ${ }^{9)}$ ，その二次的効果により 酸化にも影響を及ぼし, 治療の一助を担っている可 能性がある。特にTJ-3023は TJ-3022よりもアコニ チン類の含有量が多いためにさらなる効果が期待で きる。しかし，これまでに臨床的に附子単独の抗酸 化力を検討した報告はない。通常のブシ末服用量は 安全性を考慮して $1.5 \mathrm{~g} \sim 3 \mathrm{~g}$ と少なく, 直接作用と して抗酸化力を発揮できているのか疑問がある。そ こで，今回，健常成人に対して 2 種類のブシ末製剤 を単独で服用した場合の酸化ストレス度と抗酸化力 を測定し, ヒトにおいて附子の抗酸化作用が認めら れるのかを検討した。

\section{対象と方法}

健常成人34例を対象とした。被験者全員には事前 に安全性・中止について説明し承諾を得た。症例を ランダムに 17 例ずつに分けて，2 種類のブシ末を服
用した（ツムラ，TJ-3022，TJ-3023）。TJ-3022群は 男性11例, 女性 6 例, TJ-3023群は男性12例, 女性 5 例で両群の性別に有意差はみられなかった（P> 0.9999)。また，両群の年齢には有意差を認めなかっ た（ $\mathrm{p}=0.9332 ）$ 。両群の服用直前の酸化ストレス 度と抗酸化力の值にも有意差は認められなかった $(\mathrm{p}=0.9314, \mathrm{p}=0.6174 ）($ 表 1$) 。$

ブシ末を $3 \mathrm{~g} /$ 日分 3 で 3 日間服用した。ブシ末の 服用は市販されているミネラルウォーターを用いた。 ストレスに関与すると思われる飲食物, 睡眠, 運動 については被検者の自由として制限を加えなかった。 服用時間は食間とし, 服用直前, 服用 90 分後, 服用 72 時間後の 3 回，採血を行った。

血液の酸化ストレス度と抗酸化力の測定はフリー ラジカル 評価装置 (F.R.E.E.: Free Radical Elective Evaluator，株式会社ウイスマー）を使用した。酸化 度測定は Diacron-reactive oxygen metabolites（以下， d-ROMs テスト）によった ${ }^{10)}$ 。本テストは生体にお ける活性酸素の代謝産物であるヒドロペルオキシド 濃度をクロモグンによる呈色反応で計測する。血中 ヒドロペルオキシド量（過酸化された脂質, 蛋白質, アミノ酸，核酸など）=生体内活性酸素・フリーラ ジカル量であるため, 生体内の酸化ストレス度を総 合的に評価することができる。1 Carratelli Units（U. 
CAAR.）が過酸化水素 $0.08 \mathrm{mg} / \mathrm{dl}$ に相当する。健 常人の標準值は200-300 U.CAAR.である。抗酸化 力の測定は OXY 吸着テストによった ${ }^{11)}$ 。次亜塩素 酸（HClO）は生体内の白血球が異物を攻撃する際 に産生する最も強力な活性酸素の一種であり, 総抗 酸化バリア測定（以下， OXY 吸着テスト）は $\mathrm{HClO}$ を消去する能力を測定する。これは，有機液体の抗 酸化力を総合的に分析するテストと言える。健常人 の標準値は $350 \mu \mathrm{mol} / \mathrm{ml} \mathrm{HClO}$ 以上である。

值は中央值（最小值一最大值）で表し，集計表の 検定は Fisher's exact probability tests を用い，2 群の 比較は Mann-Whitney's U test, 経時的変化は Friedman 検定を用いた。 $\mathrm{p}<0.05 を も っ て ，$ 有意差あり とした。

\section{結果}

1. TJ-3022群の経時的変化

酸化ストレス度に関して，服用直前は305（144475）U.CAAR., 90分後は302（141－433） U.CAAR. で，72時間後は302（141-493） U.CAAR.で，有意 な変化はみられなかった（ $\mathrm{p}=0.4437 ） 。$

抗酸化力に関して，服用直前は331（200－390） $\mu \mathrm{mol} / \mathrm{ml} \mathrm{HClO} ， 90$ 分後は327 (269-417) $\mu \mathrm{mol} / \mathrm{ml}$ $\mathrm{HClO}$ で，72時間後は329 $(285-375) \mu \mathrm{mol} / \mathrm{ml} \mathrm{HClO}$ で，有意な変化はみられなかった $(\mathrm{p}=0.1926)$ （表 2 )。

\section{TJ-3023群の経時的変化}

酸化ストレス度に関して, 服用直前は303（199385）U.CAAR.，90分後は291（207－389）U.CAAR., 72時間後は292（214－394）U.CAAR.で，有意な変 化はみられなかった（ $\mathrm{p}=0.2985 ） 。$

抗酸化力に関して, 服用直前は351（245-375） $\mu \mathrm{mol} / \mathrm{ml} \mathrm{HClO}, 90$ 分後は343 $(249-379) \mu \mathrm{mol} / \mathrm{ml}$ $\mathrm{HClO}$ で，72時間後は334 $(267-415) \mu \mathrm{mol} / \mathrm{ml} \mathrm{HClO}$ で，有意な変化はみられなかった $(\mathrm{p}=0.9999 ） （$ 表 3 )。

\section{考察}

TJ-3023は TJ-3022よりも修治時間を短縮させて製 造されているため, メサコニチン，ヒパコニチン， アコニチンの含量が高まっている。我々もヒトにお けるTJ-3022と TJ-3023の比較において, メサコニ チン, アコニチン, ジェサコニチンの濃度が $\mathrm{TJ}-$ 3023群の方が有意に高值を示すことを報告した3)。 また，附子には鎮痛効果だけではなく，温熱作用，
血流量増加作用があることを我々は報告した99 。 Yamada ${ }^{12}$ は冷え症患者の血中一酸化窒素代謝産 物（NOx）を測定し，附子を含有する方剂を処方さ れた症例の方が附子を含有しない方剂を処方された 症例よりも NOx 值が高くなることを報告し，附子 にはNO 産生による血管拡張作用があることを示唆 している。このようにブシ末製剤は微小循環不全の 治療にも応用できる可能性がある。一方, NO その ものがフリーラジカルであるために他のフリーラジ カル種との相互反応から新たな活性酸素種を生じる ことも明らかになっている ${ }^{13)}$ 。特に虚血再還流時に は誘導型一酸化窒素合成酵素の発現が方進し, 血中 NO が増加するため, NOは両刃の剣といえる。in vitro の実験において小柴胡湯が NO 産生を抑制す ることによってエンドトキシンで誘発されるショッ クを回避できることが示唆されている ${ }^{14)} 。$

そこで，今回， 2 種類のブシ末を服用して酸化久 トレス度と抗酸化力を経時的に測定したが，両群と も有意な変化はみられなかった。in vitro の研究で はブシ末は用量依存的に $\mathrm{O}_{2}$ やヒドロキシラジカル を除去できることが報告されている8 ではブシ末投与量が $3 \mathrm{~g} /$ 日 3 日間と少量かつ短期間 であったため有意な変化に至らなかっただけなのか, 附子にはジペルテン型アルカロイド（アコニチン系， アチシン系)，八イゲナミン，コリネインなど様々 な成分が含有されているため抗酸化作用があっても 相殺するような作用も有しているのか, 現時点では 明らかではない。三宅らは健常人に抗酸化素材（酵 母グルカン，プロポリス，へスペリジン，ルチン， トレハロース，マビット）を30日間服用させ，酸化 ストレス度 (d-ROMs テスト), 抗酸化力 (BAPテ スト：鉄の還元力が指標）を測定し，服用前後で有 意な変化はみられなかったことを報告している ${ }^{15)}$ 。 健常人を対象とした場合, 高度の酸化ストレス状態 とは異なった反応を示す可能性もある。ただ， $3 \mathrm{~g} /$ 日のブシ末服用では逆に酸化ストレス度が高まる可 能性も否定できると思われた。附子には鎮痛作用， 温熱作用，強心作用，新陳代謝賦活作用などがある が，それらの作用には血流増加や抗酸化の関与が推 定されてきた。もちろん，d-ROMs テストは代謝産 物であるヒドロペルオキシド全般を測定しているた めに活性酸素の種類を特定することや, 半減期が数 秒であるペルオキシラジカルやアルコキシルラジカ 
ルまで測定することはできない。しかし，今回の検 討から抗酸化の影響は否定的で血流増加による影響 の方が大きいと考えられた。

通常，ブシ末は $1.5 \mathrm{~g} \sim 3 \mathrm{~g} /$ 日で使用されること が多いため，今回は $3 \mathrm{~g} /$ 日を選択したが，実際の臨 床ではさらに増量することもある。現在, 臨床使用 される抗酸化物質としては，エダラボン，ラザロイ ド，N-アセチルシステイン，DMSO（ジメチルスル

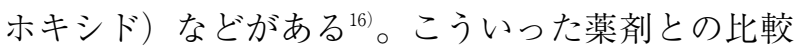
試験も有意義であろう。今後は, 東洋医学的に附子 の適応である寒証の症例に対象を限定して検討を行 う予定である。

\section{結語}

附子には鎮痛作用，温熱作用，強心作用，新陳代 謝賦活作用などあり，ヒトにおいてもブシ末単独服 用でそれらの作用に抗酸化力が関与するかを検討し た。 2 種類のブシ末を用いて健常人に対して酸化ス トレス度，抗酸化力を経時的に測定したが酸化スト レス度，抗酸化力ともに有意な変動は認められな かった。特に附子による抗酸化作用が影響している と考えられる新陳代謝賦活などにはブシ末 $3 \mathrm{~g} /$ 日の 服用では影響を及ぼさないことが示唆された。

謝辞 本研究の一部は平成 18 年度財団法人日本漢方 医学研究所研究助成金「臓器障害抑制に対する修治ブ シ末の臨床的意義」によった。

\section{文献}

1 ) 中永士師明 : 整形外科領域の疼痛疾患に対するブシ末 の有用性について日東医誌60，81-85，2009

2 ) 鈴木康之, 譲原光利, 加瀬義夫, 丸本正彦, 竹田秀一 : ブシ末 (調剤用)「ツムラ」（TJ-3023）の鎮痛および 抗アロディニア作用．薬理と治療，35，885-890， 2007

3 ) Nakae H, Fujita Y, Igarashi T, Tajimi K, Endo S : Serum aconitine concentrations after taking powdered processed Aconiti tuber. Biomedical Res，29，225-231， 2008

4 ) Huerta JM, González S, Fernández S, Patterson AM, Lasheras C : Lipid peroxidation, antioxidant status and survival in institutionalised elderly : a five-year longitudinal study. Free Radic Res，40，571-578， 2006

5 ) Sakaguchi S, Tsutsumi E, Yokota K : Preventive effects of a traditional Chinese medicine (sho-saiko-to) against oxygen toxicity and membrane damage during endotoxemia. Biol Pharm Bull， 16，782-786， 1993

6 ) Mahakunakorn P, Tohda M, Murakami Y, Matsumoto K, Watanabe H: A ntioxidant and Free Radical-Scavenging Activity of Choto-san and Its Related Constituents. Biol Pharm Bull，27，38-46，2004

7 ) 永田勝太郎, 長谷川拓也, 喜山克彦, 広門靖正 : 漢方 方剤の酸化ストレス防御系への影響（第 1 報） 漢方 方剂の抗酸化力. 日東医誌，59，242，2008

8 ) Nemoto Y, Satoh K, Toriizuka K, Hirai Y, Tobe T, Sakagami H, Nakashima H, Ida Y. : Cytotoxic and radical scavenging activity of blended herbal extracts. In Vivo, 16 : 327-32, 2002

9 ）中永士師明：ブシ末単独服用による手指の皮膚温およ び組織血流量に及ぼす影響について．日東医誌，59， 809-812, 2008

10) Cornelli U, Terranova R, Luca S, Cornelli M, Alberti A : Bioavailability and antioxidant activity of some food supplements in men and women using the D-Roms test as a marker of oxidative stress. J Nutr，131，3208-3211， 2001

11) Vassalle $C$, Masini $S$, Carpeggiani $C$, L'Abbate A, Boni $C$, Zucchelli GC: In vivo total antioxidant capacity: comparison of two different analytical methods. Clin Chem Lab Med, 42, 84-89, 2004

12) Yamada K, Suzuki E, Nakaki T, Watanabe S, Kanba S : Aconiti tuber increases plasma nitrite and nitrate levels in humans. J Ethnopharmacol，96，165-169， 2005

13) Katusic ZS : Vascular endothelial dysfunction : does tetrahydrobiopterin play a role? Am J Physiol Heart Circ Physiol, 281, H981-986, 2001

14) Sakaguchi S, Furusawa S, Yokota K, Sasaki K, Takayanagi M, Takayanagi Y : Effects of antitumor activity and protection of shock symptoms by a traditional Chinese medicine (sho-saiko-to) in recombinant human tumor necrosis factor administered mice. Biol Pharm Bull, 19, 14741478, 1996

15）三宅智恵子, 春日井達造, 通木俊逸, 植田美津江 : 抗 酸化素材の効果判定 ボランティアを対象とした臨床 データの比較検討。日未病システム会誌，11，108110, 2005

16) Dohi $K$, Satoh K, Nakamachi $T$, Yofu S, Hiratsuka $K$, Nakamura S, Ohtaki H, Yoshikawa T, Shioda S, Aruga T : Does edaravone (MCI-186) act as an antioxidant and a neuroprotector in experimental traumatic brain injury? Antioxid Redox Signal， 9 ，281-287， 2007 